Dossiê Especial: Experiências do PIBID na formação inicial e continuada de professores de línguas estrangeiras

HIBARINO \& NODARI (orgs)

Revista X, vol.1, 2015

\title{
“BEING ON THE SAME BOAT": PIBID AND TEACHING PRACTICUM AS ENHANCEMENT FOR A TEACHER EDUCATOR'S LEARNING
}

\begin{abstract}
"Estando no mesmo barco": PIBID e prática de ensino como potencializadores do aprendizado para uma formadora de professores
\end{abstract}

Michelle EL KADRI ${ }^{1}$

\begin{abstract}
Research on PIBID indicates it has fostered changes in the way participants are becoming teachers (CASTELA, 2013b; MATEUS; EL KADRI; SILVA, 2013; RIBEIRO; CASTELA; JUSTINA, 2013). However, little has been said about teacher's educator' learning in this context. Thus, in this paper, I describe the general contributions of participating and writing about PIBID for my own personal development, as the very product of my participation in the program while articulating PIBID and Teaching practicum.
\end{abstract}

Keywords: PIBID; teacher educator; experience.

Resumo: Pesquisas sobre o PIBID indicam que o programa tem fomentado mudanças no modo como seus participantes se tornam professores (CASTELA, 2013b; MATEUS; EL KADRI; SILVA, 2013; RIBEIRO; CASTELA; JUSTINA, 2013). Contudo, pouco tem se dito sobre o aprendizado de formadores neste contexto. Portanto, nesse artigo, descrevo as contribuições gerais de participar e escrever sobre o PIBID para o meu próprio desenvolvimento enquanto formadora de professores em uma experiência que articula PIBID e a prática de ensino.

Palavras-chave: PIBID; formação de formadores; experiência.

\section{Beginning the talk}

“não há ensino sem pesquisa e pesquisa sem ensino [...], ensino porque busco, porque indaguei, porque indago e me indago. Pesquiso para constatar, constatando, intervenho, intervindo educo e me educo [...]”.

Paulo Freire (2002, p.14)

PIBID, one of the initiatives taken by Brazilian government on the need to prepare teachers to address the country's demands regarding education, has acted as a catalyst for a massive mobilization of universities in the context of 'National Politicy for Teacher Education'. Launched in 2007 within federal universities and then in 2009 among state universities, PIBID is considered one component of the set established by the PDE. It is characterized by the government as the educational component of the "Plano de Aceleração

\footnotetext{
${ }^{1}$ Ph.D in Language Studies. Professor at Londrina State University. mielkadri@ hotmail.com.
} 


\section{Dossiê Especial: Experiências do PIBID na formação inicial e continuada de professores de línguas estrangeiras \\ HIBARINO \& NODARI (orgs) \\ Revista X, vol.1, 2015}

do Crescimento - PAC" or the Growing Enhancement Plan (AS NOVAS..., 2007, p. 31). According to the documents of the program, the main tenets for teacher education in PIBID are to promote the integration between theory and practice through the early insertion of novice teachers in public schools and to encourage schools to play more central roles in teacher education by positioning the schoolteachers as co-supervisors.

PIBID has been incorporated into several teaching education programs in Brazil. Research on it has shown that PIBID collaborates with the overcoming of gaps in teacher education programs, mainly the gap between theory and practice and the relationship gap between university and school (JUSTINA; RIBEIRO; CASTELA, 2013). It also has provided an appropriate context for the education of language teachers through different frameworks and plans of action (CASTELA, 2013b; MATEUS; EL KADRI; SILVA, 2013). Research has also shown that PIBID has been expanding and presenting more positive results on a daily basis regarding teaching in public schools (ARRUDA; BUENO, 2013). Moreover, it has stimulated changes in the activity of educating English teachers (ORTENZI et al., 2013). It seems to be a consensus that the program has cultivated changes in the way participants are becoming teachers (CASTELA, 2013b; GAFFURI, 2013; JORDÃO et al., 2013; MATEUS; EL KADRI, 2012; MATEUS; EL KADRI; SILVA, 2013; RIBEIRO; CASTELA; JUSTINA, 2013).

The emphasis placed on research - in general - seem to represent PIBID as a possibility for constructing novice teachers' identification with the school, contributing to the university-school relationship and creating opportunities for professional development (CORREA; PORTELA, 2012, p. 234). Gimenez (2012), for example, asserts that public initiatives such as PIBID (a) have demonstrated that the creation of communities is an enriching way to promote professional development associated with schools; (b) may be one of the solutions needed to turn teacher education practices more equitable with school practices and (c) allow the crafting of professional identities (GIMENEZ, 2013a). Jordão (2013) emphasizes it has transformed the conception of public school as a productive locus for learning.

These studies demonstrate the impact of PIBID on teacher education programs. However, in general, what most of the research on PIBID presents so far are the aims, actions and general results of the projects. It seems to me there is one main gap in this context: (a) little research focused on how teacher education programs are re-constructing their curriculum 
Dossiê Especial: Experiências do PIBID na formação inicial e continuada de professores de

línguas estrangeiras

HIBARINO \& NODARI (orgs)

Revista X, vol.1, 2015

(b) none focused on the learning of one the main participants in this context: the teacher educator, which also plays an important and central role in this context.

Thus, it is precisely these two gaps I intent to discuss in this paper: how PIBID should be linked to Teaching practicum and what have I learned - as a teacher educator - from the experience of studying teacher learning within schools. Although I have several papers on the experience of novice teacher's identities within the program (EL KADRI; ROTH, 2014; MATEUS; EL KADRI, 2012) and a doctoral thesis on novice teachers' transformation (EL KADRI, 2014), this paper departs and expands from the previous research and focuses on my own learning - a part of the experience that was not document in the previous papers.

Thus, I start this discussion by (a) elaborating on my practical experience within PIBID since 2009 of addressing the 'controversial issue' regarding PIBID and Teaching practicum, (b) presenting the benefits of bridging PIBID and Teaching practicum based on the research carried out in this context and (c) presenting my report on my own experience as a new teacher educator in PIBID context. In this part of the paper, I describe the general contributions of participating and writing about PIBID for my own personal development, as the very product of my participation in the program. My aim of doing so is to present PIBID as a context to foster new models, new identities and new scenarios for teacher learning in Brazil, that is, as learning communities for all the stakeholders involved. This is so because from my perspective, PIBID is, besides creating new ways of acting, interacting, representing and beings of new teachers (EL KADRI, 2014), it also has the potential to create new teacher educators' identities.

\section{Expanding the concepts from my experience: What I learned from joining PIBID and the Practicum}

Fashioning alternative possibilities for the positioning of novice teachers and the implications of this reorganization are significant issues that warrant discussion in the process of educating teachers. With PIBID, ideas of teacher educators fostering collaborative environments were able to come to fruition. Cristovão et al. (2006) pointed out the paramount role public policies play in the development of collaborative practices within teacher education programs. Although I am aware that PIBID is not considered the same as a 'teaching practicum' -and such was not the objective of CAPES - a comparison and contrast between the two has become a topic of great debate. The $2^{\text {nd }}$ Forum of PIBID in Paraná, for 
Dossiê Especial: Experiências do PIBID na formação inicial e continuada de professores de

línguas estrangeiras

HIBARINO \& NODARI (orgs)

Revista X, vol.1, 2015

example, demonstrated that executing PIBID alongside the teaching practicum is a great concern to many teacher educators.

The main controversial issue of the debate is the fact that CAPES defends the idea that PIBID should not be implemented during the teaching practicum (in this sense, PIBID does not equate to teaching practicum); rather, PIBID's aim should be connecting novice teachers to schools earlier in their careers. However, several initiatives presented in seminars acknowledge that the teaching practicum within PIBID would have the potential to change the way supervisors relate to novice teachers and the way teacher educators relate to supervisors and vice versa, which is often difficult to achieve within non-PIBID formats (MATEUS; EL KADRI, EL KADRI, 2012). It has been recognized as beneficial that the teaching practicum should be reconsidered taking into account participants' experience in PIBID.

What is important in this debate is that the advantage of such a merge is now acknowledged by PIBID participants all over Brazil and has been seen as a topic of discussion in many events (see, for example, $2^{\text {nd }}$ Forum do PIBID, October, 2013). It has also been acknowledged that the insertion of novice teachers in PIBID has offered more acting opportunities than the teaching practicum and it has expanded the dialogue between schools and universities (CASTELA, 2013b).

Most novice teachers who were also participants of PIBID chose to complete their teaching practicum in the same schools they were involved in during the program (RIBEIRO; CASTELA; LANGER, 2013). That being said, the interference of the experience of PIBID in teaching and planning during teaching practicum is clearly visible (EL KADRI; GIMENEZ, 2013; MATEUS; EL KADRI, 2012).

In the institution in which I work and consequently, my studies were carried out, the education of the English language teacher has been the focus of research for more than a decade. The resulting research literature produced by this group reveals the commitment to understanding the process of educating teachers and to creating possibilities for new and productive forms of activity by researching within of the context of their own work. The production of teacher educators within academia, as seen within this research, demonstrates a great concern for implementing new and meaningful teaching practicum activities and understanding the process of educating teachers (CRISTOVÃO, 2005; GAMERO; CRISTOVÃO, 2013; 2013a, 2013b; ORTENZI, 2007a, 2007b).

Consequently, this study is driven by the development of a socio-cultural-historical theoretical framework and by two successful and positive local experiences that aimed at 
Dossiê Especial: Experiências do PIBID na formação inicial e continuada de professores de línguas estrangeiras

HIBARINO \& NODARI (orgs)

Revista X, vol.1, 2015

strengthening the university-school relationship through collaborative teacher education (CRISTOVÃO, 2005; GIMENEZ; CRISTOVÃO, 2004; MATEUS, 2005). More recently, collaborative practices during teaching practicum have been the focus of teacher educators' attention in the institution (EL KADRI; GIMENEZ, 2013; EL KADRI; MATEUS; PICONI, 2013; MATEUS; EL KADRI, 2012; ORTENZI, 2013; SOUZA-FIORI, 2013). The PIBID arrangement, therefore, was propelled by a natural development of the practices already initiated in the institution.

At UEL, the teacher educator participants of the project saw the convergence of objectives and included teaching practicum activities within PIBID for two main reasons. First, because at that particular time the internship guidelines of the program allowed for the practicum to be carried out through alternative arrangements such as projects. Secondly, because, as I have already noted, it allowed for a continuity of history regarding collaborative teacher education based on socio-cultural-historical theory tenets. Initial and continuing teacher education at the institution valued collaboration among the participants and because of this novice teachers, teacher educators and schoolteachers were provided with new learning opportunities that would not necessarily occur otherwise (MATEUS, 2005, GAMERO; CRISTOVÃO, 2013). Subsequently, the PIBID program with the English language teacher education project at UEL followed these footsteps.

Our proposal of carrying out the teaching practicum within PIBID comes from the recognition that the relations developed at school during PIBID seem to contribute to teaching practicum relations when carried out at those same schools. More precisely, I am not arguing that PIBID is 'equivalent' or 'could potentially replace' the practicum rather, I affirm, it enhances the process as a whole and alters the way the teaching practicum has been understood and arranged if the participants continue to work at the same school. It is not a matter of "replacing' the teaching practicum with PIBID but rather using the "structure" of PIBID to enhance the practicum. I argue then, that although PIBID is not a substitute for the teaching practicum, it brings new implications, organizational strategies and possibilities for the practicum.

One of the main arguments for doing so is that our research have shown that PIBID aligned with Teaching Practicum has solved many of the contradictions experienced in 'traditional' teaching practicum (MATEUS; EL KADRI, 2012; EL KADRI; GIMENEZ, 2013; EL KADRI; ROTH, 2015; EL KADRI, 2014). In more traditional spaces - or in the non-PIBID context - the practicum is generally seen as a space which has yet to provide the 


\section{Dossiê Especial: Experiências do PIBID na formação inicial e continuada de professores de línguas estrangeiras \\ HIBARINO \& NODARI (orgs) \\ Revista X, vol.1, 2015}

possibility of overcoming the dichotomies which separate the university from the school, the academic knowledge and the school praxis, the teacher educators and novice teachers. Some studies have shown that 'traditional' teaching practicum may afford the same results when the working conditions are similar to PIBID (CRISTOVÃO et al., 2006; MATEUS, 2005). Taking into account the structure provided by PIBID, the teaching practicum might have the potential to transform the relations between the school and university as a result of new arrangements that also, potentially, transcend barriers. In the transformation process of these practices, new discourses are simultaneously created as instrument and result of these new social practices.

A recent research carried out in teaching practicum at the institution, reveals that collaborative projects have been successful in the sense that they provide opportunities for the learning of all participants (EL KADRI, 2013b). Moreover, these practices seem to be enhanced by public policies - such as PIBID and PRODOCÊNCIA - which have been fostering new arrangements and practices during the teaching practicum, contributing to a collaborative learning scenario (see, for example, MATEUS; EL KADRI; SILVA, 2013).

As pointed out in previously studies, the results of a recent literature review (EL KADRI, 2013a; ) carried out in our local interpretation of the context of the teaching practicum within PIBID has shown that (a) teaching experience and social relations are conditions for teacher development (EL KADRI; ROTH, 2013); (b) working closely with the school has transformed the relations with schoolteachers with initial teacher education, demonstrating that schoolteachers legitimately participate in the group (GAFFURI, 2013), although there relation with the teacher educator is still asymmetrical (CHIMENTÃO; SOUZA-FIORI, 2013); (c) the relationship between university-schools has been transformed in the process of accepting what each participant brings to the learning of the group (EL KADRI; PICONI; MATEUS, 2013); (d) novice teachers feel more engaged and participate in relevant ways when tools that provide them with the opportunity to be producers of the contents are used, one such being the use of narratives (ORTENZI, 2013); (e) novice teachers are also repositioned as teacher-researchers (ORTENZI et al., 2014); (f) novice teachers have reported successful experiences in this context (EL KADRI; GIMENEZ, 2013). Thus, a longitudinal study carried out during two years demonstrated that teacher identities are transformed in regards to their ways of acting, interacting, representing and being when PIBID is associated to innovative practices: teachers tend to act as more legitimate participants at school as they interact in more active ways through dialogical practices, 
Dossiê Especial: Experiências do PIBID na formação inicial e continuada de professores de

línguas estrangeiras

HIBARINO \& NODARI (orgs)

Revista X, vol.1, 2015

represent themselves as agential with the ability to transform their present context and become an accountable actor in said context (EL KADRI, 2014).

\section{My practical experience: merging PIBID and Teaching Practicum to deal with the contradictions}

What is important to note is that PIBID English language teacher education project in our institution followed a historical involvement with initial and continuing teacher education that valued collaboration among the participants (CRISTOVÃO et al., 2006; FURTOSO et al., 2009; MATEUS; 2005; ORTENZI, 2009). Forty (40) of our pre-service teachers participate in the program and they generally stay in the program for two years. Teacher educators who supervise the teaching practicum are those who participate in PIBID. Thus, the teaching practicum - for those participating in PIBID -was merged with the PIBID activities. In this merging, working at the same school and with the same schoolteacher supervisor, which facilitated the work, thus improved the relations between the participants and concentrated the activities towards a specific site. While PIBID requires a 360-hr/year commitment, the teaching practicum at the institution requires 200. Participants of the teaching practicum within PIBID, thus, had 560 hours of required engagement. This means that novice teachers spent, at least three mornings at school during the whole year. Thus, the objectives and practices of both systems were maintained.

Although there is the need to consider the different genres in which these objectives appear - in discipline programs, in teaching practicum, and in PIBID edict, in PIBID itself - it is possible to discuss some considerations which allow us to visualize how the teaching practicum within PIBID was conducted. The objectives of the teaching practicum and PIBID are quite similar with regard to the development of novice teachers' teaching skills. However, in teaching practicum, the development of novice teacher seems to be described only at the individual level. There is no explicit mention to the development of schools and other participants. In this sense, the objectives established by PIBID seem to expand the objectives. Besides the professional development of novice teachers, there seems to be great concern with the development of relationships between university and school, a collaborative culture and the role of the school as an educating entity.

Although the research on teaching practicum at the institution - as presented in the previous section - consistently highlights the concern with the very same objectives outlined in PIBID, the fact that these tenets are not made explicit in the discipline programs may limit 


\section{Dossiê Especial: Experiências do PIBID na formação inicial e continuada de professores de línguas estrangeiras \\ HIBARINO \& NODARI (orgs) \\ Revista X, vol.1, 2015}

the spectrum of actions of the participants. Likewise, the explicitness of such tenets in PIBID documentation seems to create the need for collaborative education (through the reorganization of roles, methodologies, practices, beliefs, etc.). Thus, it seems to enhance the creation of communities when attempting to transform teachers' learning. There is thus a predicted action implied in the constitution of a professional learning network for teachers' development, with the potential to constitute a professional identity (GIMENEZ, 2013a). It is obvious, tough, that it may also reinforce traditional practices, roles and hierarchical positions. This fact, however, justifies the need for investigating how participants are organizing, working, acting, representing and being in this organization in each local practice. In the re-configuration within our context, the teaching practicum within PIBID created a third-space that was neither solely the teaching practicum nor strictly PIBID.

The merging of both contexts thus created a new configuration of the practicum. In general, activities in PIBID not merged with the teaching practicum focus mainly in extracurricular activities at schools and the production of didactic materials (see, for example, EL KADRI; CHIMENTÃO, 2013). However, merged with the teaching practicum, both activity systems seem to be enhanced. Different from independent teaching practicum, novice teachers, from various levels in their program, work together, constituting a new possibility for the development of ZPD. They would spend more time at schools and become responsible for one group of students during all the stages of teaching throughout the entire year (selection of contents, planning, teaching, evaluating, giving feedback, etc.). Time is important issue in this experience because it contributes to their education by confronting the theory practice paradigm and garnering experiences of learning and problem-solving (ZEULLI et al., 2013).

Moreover, they participate often in the collective spaces at schools and have the support of the schoolteacher and the teacher educator during the whole process. The mutual understanding between the participants in the attempt to achieve the objectives established by PIBID - one of them being to innovate in public schools - appears to create conditions for collective work because novice teachers are concentrated in the same schools working with the same schoolteachers. Thus, better conditions for work are created for teacher educators who do not have to travel to different sites; who have more intensive contact with schools with regards to collaborating and organizing schoolteachers' activity hours in one morning. In doing so, schoolteacher participation in the process is enhanced, easing the social relations between the participants. Likewise, the school staff appears to feel more confident and 


\section{Dossiê Especial: Experiências do PIBID na formação inicial e continuada de professores de línguas estrangeiras \\ HIBARINO \& NODARI (orgs) \\ Revista X, vol.1, 2015}

actually believe that opportunities will arise from the increased teaching staff and from hosting and working with novice teachers (with different kinds of knowledge and experiences) and teacher educators, feats not normally actualized in traditional contexts. In the specific local context, the education of teachers appears incidental as all the participants collaboratively attempt to innovate while re-constructing the English teaching curriculum (see EL KADRI; ROTH, 2014) through $\{\text { coteaching | cogenerative dialogues }\}^{2}$.

Merging PIBID and the teaching practicum, however, allows space for the creation of a new position of the teaching practicum participants at schools. Schoolteachers frequently consider the teaching practicum a disturbance-so much so that even if a principal were willing to host novice teachers s/he might "struggle to identify suitable cooperating teachers" (ROTH; TOBIN, 2002a, p. 100) - rather than as a means for transforming teaching, learning, schools, teachers, or education (EL KADRI, ROTH, 2014). Therefore, the idea of having all the participants working collaboratively in order to innovate in English teaching may contribute to a view of the practicum in which it is appears beneficial to school life and enhances the quality of English teaching.

Merging teaching practicum with PIBID through \{coteaching $\mid$ cogenerative dialogue challenges the way teaching practicum is actually conceived in many teacher education programs in the country as it sheds light on many of its shortcomings. First, instead of the position of the teacher educator that uses the school environment to fulfill the curriculum of the university without offering integrated proposal to benefit the schools, the teacher educator's role is redesigned through \{coteaching | cogenerative dialogue\} which helps to construct an alternate proposal for the teaching practicum (e.g. redesign the curriculum). This new organization helped to deal with the contradiction that Brazilian schoolteachers often deem the way teacher educators relate to the schools as unsatisfactory (GIMENEZ; PEREIRA, 2007). Second, novice teachers, teacher educators and schoolteachers are working together in the whole process of teaching (planning, teaching, evaluating and participating more actively in school life through a Students Evaluation Board and Planning Week). This helps to avoid school staff complaints of the lack of communicative opportunities between teacher educators and novice teachers and the school (GIMENEZ; PEREIRA, 2007) and ultimately addresses the schoolteachers desire for novice

\footnotetext{
${ }^{2}$ Theorethical and methodological approach under the socio-cultural-historical paradigm for educating teachers. It is interpreted as a methodology for the improvement of teacher education by providing new opportunities for learning to teach and for the enhancement of student learning, but also as means to overcome the theory/practice gap. See El Kadri (2014) for an extensive review on it.
} 


\section{Dossiê Especial: Experiências do PIBID na formação inicial e continuada de professores de línguas estrangeiras \\ HIBARINO \& NODARI (orgs) \\ Revista X, vol.1, 2015}

teachers to be aware of the classes, the planning, the context and school life (BIAZI; GIMENEZ; STUTZ, 2011).

This organization helped me to deal with the contradiction of the practicum (see for example, BARCELOS; BATISTA; ANDRADE， 2004; JORDÃO; BÜHRER， 2013; ORTENZI, 2009a, XAVIER, 2004). First, teachers-in-training often see the school as a place where they implement and execute projects, in some settings without consulting with the schoolteachers. There is evidence that, in some cases, novice teachers regard schoolteachers as professionals with no real power to act $^{3}$ and who are often more concerned with protecting their image as a teacher within the school (XAVIER, 2006). Studies also report that during the practicum, novice teachers often feel they are not respected in the school context (GIMENEZ et al., 2000); they consider themselves students rather than teachers (ORTENZI et al., 2003). The general attitude that persists among novice teachers is to regard the practicum as a period of experimentation and implementation of theories all the while developing a general sense of the existence of an abyss between the contents of university courses and the realities of the actual classroom (DANIEL, L., 2009).

Moreover, schoolteachers involved in the practicum often also view the experience negatively. They see the practicum as (a) a disturbance particularly when having to be observed and (b) as requiring additional work above and beyond their normal workload, specifically when prompted to be supervisors (GIMENEZ; PEREIRA, 2007). As a result, schoolteachers frequently feel as though they are not responsible for the process of educating novice teachers and guiding them into the profession. The practicum is viewed as making a marginal contribution to the quality of their teaching (BIAZI; GIMENEZ; STUTZ, 2011) and professional development. Occasionally, schoolteachers also see the practicum as an opportunity to be relieved of their normal tasks, allowing them to complete other tasks. In this scenario, novice teachers are interpreted as assistants and monitors with little commitment and responsibility to the school environment or as mere users of the facilities and inexperienced learners (XAVIER, 2006).

However, results of this merging included having novice teachers, schoolteachers and teacher educators engaged in teaching for a longer period of time, working with a group of students during the whole year, being sensitive to the school schedule (in a way that changed the teaching practicum schedule to one that fits the schools environment) and working

\footnotetext{
${ }^{3}$ I use this term in this paper to refer to the capacity of individuals to participate in creating their lives in the world rather than merely being determined by environmental circumstances.
} 
Dossiê Especial: Experiências do PIBID na formação inicial e continuada de professores de línguas estrangeiras

HIBARINO \& NODARI (orgs)

Revista X, vol.1, 2015

collaboratively through coteaching | cogenerative dialogue\}. The traditional roles of participation (teacher educator supervising, schoolteachers "giving room" to novice teachers" as "temporary trainees" at schools) during teaching practicum thus gave rise to new ones: the teacher educator was also co-teaching, the schoolteachers were also enacting the role of cosupervisor and co-teaching, and the novice teachers took up the role of schoolteacher and teacher educator.

These transformations are contributions to the redesign of the perceptions of the participants in the teaching practicum. In our case, novice teachers demonstrated such a great level of commitment and responsibility that it warranted a change in the school's perception of novice teachers. This contributed to address another contradiction of the practicum, which is a time characterized by conflictive situations, especially in regards to the positioning of the student-teacher as an occasional learner and at other time a teacher (GIMENEZ, 2004; BARCELOS; BATISTA; ANDRADE, 2004; JORDÃO, 2013). Owing to its hybrid characterization (belonging both to school and university), the practicum is at times seen as "a third place" or no place at all.

\section{What I learned as a teacher educator}

In this part of the paper, I describe the general contributions of participating and writing about PIBID for my own personal development, as a product of my participation in the program.

In my attempt to understand what is being learned and how by the participants of this experience, the concept of participation shifts from meaning merely "being present" to starting to became clearer to me and being reconceptualized to an extent as it starts to mean “finding one's voice". I was able to re-conceptualize what I believe teachers' identities are all about: in a previously study I showed a novice teacher (Aline) had found her voice when she identified herself as a PIBIANA: a voice of proud for working to enhance education, a voice she has not felt before in other contexts and in other teacher education programs (EL KADRI; ROTH, 2013); then, I was able to understand this identity was not solely identification; rather it also meant differentiation (EL KADRI, 2014). I reflect on how another novice teacher (Jefferson) found his voice as a legitimate participant as he cotaught and researched on contradictions, how he literally begins to speak on his own, and with his own intentions (EL KADRI; ROTH, 2015b, EL KADRI, 2014) and how the school supervisor (Alice) - found 


\section{Dossiê Especial: Experiências do PIBID na formação inicial e continuada de professores de línguas estrangeiras \\ HIBARINO \& NODARI (orgs) \\ Revista X, vol.1, 2015}

her voice as a genuine and legitimate participant during teaching practicum as a way to enhance the learning of her students and the teaching practicum itself (EL KADRI, forthcoming) and its participants found their own voice at school by working collectively (EL KADRI; ROTH, 2015a).As pointed out in El Kadri and Roth (2015b ), I learned that there is a transformative potential that derives from fully integrating practicum participants in school affairs generally and in the redesign of curriculum specifically. Such transformative potential was noticed when the practicum became (a) the locus not only for the transformation of new teachers, practicing schoolteachers, teacher educators, and students but also for the transformation of schools, university/school partnerships, and the practicum itself (EL KADRI; ROTH, 2015b). Moreover, I noticed much of this was the result of the expansive learning that occurred in the formation of a new form of activity that was collectively generated (EL KADRI; ROTH, forthcoming; EL KADRI; PASSONI, 2013). Thus, this "collectively generated activity" was pointed out by the new teachers as meaningful practices (EL KADRI; GIMENEZ, 2013). To them, becoming accountable actors in the curriculum production and the sense of being innovating and transforming the school in the decisions in teaching practicum made the difference regarding the way they saw themselves as teachers (EL KADRI; GIMENEZ, 2013; EL KADRI, 2014).

Reflecting on my own journey as a teacher educator, participation has always been a central aspect of it: participating in the planning, coteaching the class and cogenerating ideas about it, shifting the leading role of 'supervising' and re-framing the English curriculum at school. I remember people telling me that I had grown a lot and asking me what I was doing and if I was studying too much. I did not know what to say because, in fact, I was not "studying" but I also did not know what I was doing to have "such growth" as people used to say. What I noticed by stepping back and writing about PIBID is that I was, in fact, participating. I noticed participation was a key concept when I realized that the tremendous transformation in my own development occurred through my constant participation in the teacher education social practices at the university. Although my participation in several projects and initiatives were seen by some as a way to stand out, I knew something was going on but I did not know how to describe it back then. I just knew the more I used to participate in different kinds of activities, the best I could perform in another activity even though they were considered apart from each other. For me however, they all culminated in my role during teaching practicum. By writing about PIBID, I realized what was in fact happening to me was a process of conscientização (FREIRE, 2002) and what Vygostkij (2005, p. 1021) had 


\section{Dossiê Especial: Experiências do PIBID na formação inicial e continuada de professores de línguas estrangeiras \\ HIBARINO \& NODARI (orgs) \\ Revista X, vol.1, 2015}

highlighted by saying that "Any higher psychological function was external; this means that it was social; before becoming a function, it was the social relation between two people" (VYGOTSKIJ, 2005, p. 1021). It was just by carrying out research on PIBID and participating that it occurred to me that the very societal relations that a person participates in - and, therefore, constitutes and is constituted by - transforms participation. It is, therefore, only because of my previous development that participation in this experience turns out to be the central core of this study. If participating allowed me to transform and develop, what could I learn from participating at school in new ways? I wonder that, if this was how it worked for me, maybe, this is how it was working for the teachers-to-be I was working with. This awareness shaped my way to conduct the teaching practicum.

Participating and writing about PIBID allowed me to understand my role as a teacher educator. By studying Aline's trajectory as a learner (EL KADRI; ROTH, 2013; EL KADRI, 2014), I learned how to be sensitive to new-teachers who already were legitimate teachers in other contexts and understand that however difficult it might be for others in the relation mainly me, as a teacher educator - when there is resistance, it is only through continued relation that change may occur. Understanding it changed the way I see resistance and negativity in the context of teaching practicum. By studying Jefferson's trajectory as a learner (EL KADRI; ROTH, 2015; EL KADRI, 2014), I begin to understand that it is ok not wanting to be a teacher during the course because it is in the process of participating in teaching social practices that one becomes a teacher and develop consciousness and identification with the profession. By writing the ethnography study of the teaching practicum experience (EL KADRI; ROTH, forthcoming; EL KADRI, 2014) in the scope of PIBID I learned how much we are able to accomplish if we work collectively towards the enhancement of teaching. I also learned it (a) is not a case of having collaboration as the ultimate aim but rather collaborating as a means to achieve something bigger and (b) the talk on collaborative models for teaching education lies, in fact, in the need to place the societal relations as a core of teaching education programs because it is the locus of all higher psychological functions for all of those participating in a societal relation.

By choosing \{coteaching | cogenerative dialogue as a methodology to be used in PIBID and Teaching Practicum, I also learned that the positions we both take are the result of a dynamic and locally established process that is being constructed and reconstructed within the classroom and evolves in relations (EL KADRI, 2014). I realized (and experienced!) the more dialogic the process of interaction is, the more it allows agency because it is in spaces of 


\section{Dossiê Especial: Experiências do PIBID na formação inicial e continuada de professores de línguas estrangeiras \\ HIBARINO \& NODARI (orgs) \\ Revista X, vol.1, 2015}

shared practice that identity, agency, collective action, and novel cultural forms can grow (EL KADRI, 2014). In this sense, writing about my experience in PIBID allowed me to reinforce the view that transmissive knowledge is not the point even if I have to deal with beliefs from students saying "you are not playing the role we'd expect you to be".

Again, this experience also allowed me to address some questions that I raised: The questions "How am I going to work in a context where my discourse is seen only as a 'theory'? How can I teach knowing that it does not make sense to new teachers when they go to school? How can I supervise students in their teaching practicum and actually contribute to their development? What could I do? What other possibilities were there for educating teachers?" addressed the contradiction I felt of feeling with no power to act and the gap between theory and practice which culminates in the resistance generally found in the teaching practicum field. The way I found to address it was participating with new teachers and cooperating teachers on a regular basis in all the phases of teaching: planning, teaching and evaluating. This participation gave me a sense of belonging, as I shifted from being "the university teacher educator" who does not know anything about practice and talks about theories that do not work in practice to someone who was experiencing the field and talking about this experience. I felt as a legitimate participant during teaching practicum and a lot less as the supervisor to whom the new teachers had to agree. I felt "I had a saying" in the context and also at school. This feeling occurred not only during teaching practicum but also when this experience was a feedback to my classes in the initial teacher education and to ongoing teacher education programs (during PDE courses, for example). During these moments, teachers often show great level of interest of working with teacher educator as they saw the didactic material produced and listened to the experience of the participants. One of the teachers, for example, gave feedback me by saying that the activities we prepared based on ENEM's test allowed her to work with her own students in a way she had never imagined. The dynamic of inviting school staff to collaborate with us talking to new teachers about school guidelines (such as the Pedagogical Political Project) and School collective meetings culminated in the school inviting me to talk about school planning at the Pedagogical Week to other teachers in order to contribute to this sense of belonging.

My initial question regarding "what could be done in order to overcome the sense of passivity and negativity during teaching practicum?" was also answered through this experience. This participation contributed to my understanding of how agency is developed. I came to realize it is not something "I could give" to my students but rather something they 


\section{Dossiê Especial: Experiências do PIBID na formação inicial e continuada de professores de línguas estrangeiras \\ HIBARINO \& NODARI (orgs) \\ Revista X, vol.1, 2015}

also had to participate in order to have it developed. However, it also made me understand that my role is to provide contexts with appropriate resource so they can participate in and be in fact subject to and subjected to the relations (EL KADRI; ROTH, 2015b).

Such studies also made me aware of not only the social-historical reasons regarding the resistance and negativity I found in this context but also the possibilities to deal with practical contradictions found in the field regarding the way participants are seen and see themselves during teaching practicum. Although human beings, on their own, often feel that they cannot change the conditions and this fact becomes salient during teaching practicum as individuals do not recognize themselves as agents of change and with power to act in their own context, I learned that collectively, transformation can be brought about in a new form of activity, which transcends the potential of any individual actor. I learned that by dealing with contradictions arisen from the praxis and by having the students as primary subjects of the activity, we are able to transform our roles at school.

This participation also allowed me with opportunities to construct principles that should inform my own approach to teaching practicum. Besides those ones already presented by the extensive literature ${ }^{4}$ carrying out this study afforded me with new level of conscientização regarding the teaching practicum. Some principles started to inform my practices: I realized (a) establishing contexts for the development of societal relations during teaching practicum through substantial periods of time should be the central aspect of it; (b) Teachers are not only subjects to but also subject to the conditions they find in their teaching education program;(c) Participation is a pre-requisite for teacher development ; (d) Cogenerative dialogue provides teachers with appropriate context for the development of interactional space to deal with contradictions during teaching practicum; (e) Having the students as primary subjects of teaching practicum enables school transformation.

As in this journey I tried to bridge my two worlds - working with teachers during teaching practicum and being a doctoral student, I realized that investigating the developments afforded by recent public policy concomitant to the possibility of investigating my own practice, educate English teachers and innovate in English teaching as part of my daily work made sense to me. I do not see any other way (for me) to carry out research that it

\footnotetext{
${ }^{4}$ such as the need to (a) establish partnerships between school-university; (b) join teacher education to school development; (c) involve all the stakeholders in the process of teaching education; (d) redirect the aim of the practicum towards renewal and change rather than the transmission of a set of predetermined teaching skills; (e) redirect the aim of teaching practicum toward student's learning; (f) embed teaching practicum in a comprehensive school-improvement program and $(\mathrm{g})$ establish meaningful relationships between all the participants.
} 


\section{Dossiê Especial: Experiências do PIBID na formação inicial e continuada de professores de línguas estrangeiras \\ HIBARINO \& NODARI (orgs) \\ Revista X, vol.1, 2015}

is not intrinsically involved to my daily work and does not improve my work condition. The contribution of studying teacher education within PIBID to my professional development also lies in (a) giving me great power to act in my everyday work and (b) allowing me to integrate teaching and research as layers of the same activity.

My development also came about regarding the understanding and the implementation of the \{coteaching | cogenerative dialoguing\}. Although I am aware of the fact that other contexts might have better conditions for its implementation (see EL KADRI (2014) for a deep review on it), I realized the opportunity of appropriating myself with the theoretical framework of it, contextualizing it and implementing it in our own ways (e.g. students were not included in cogenerative dialogues due to difficult arrangement at school) as an opportunity to discuss the concept. Participating and writing about this experience allowed me to reconsider and reiterate my own views on the definition of the concept. Defining coteaching as only and whether the teacher educator is present, in my views, is to overemphasize the role of the teacher educator and diminish the role of having, for example, two cooperating teachers working together or a new teacher with a cooperating teacher. This recognition neither implicate in saying that the teacher educator should not coteach nor is it an attempt to exclude the teacher educator from this process as a way of saying "I do not want to redesign my role". It is, in fact, learning that came from the praxis of coteaching: amazing things|learning also happen and occur when the teacher educator is not present. In my experience of coteaching, participating twice a week in coteaching classes (and not four classes a week) did not diminish the potential of the framework. Rather, it empowered the cooperating teacher in enacting the role of the teacher educator more actively when I was not present. My aim here is to say that (a) teacher educators should be embedded in praxis on a regular basis but it does not mean to co-teach all the classes. When he|she is present, one should contribute as a fully participant rather than just supervising but it does mean his|her presence is mandatory in order to have coteaching implemented. This acknowledgement came later to me, as I felt myself in debt and not in peace when I could not be present every day at school (even when I was coteaching at least twice a week at school). I also support this view because being at school and having the teacher educator role reconceptualized does not mean "only" coteaching but also implies talking to educational administrative staff, organizing room for meeting, talking to the principal, asking for permission and collaboration and organizing cogenerative dialogues, for example. Many times I caught myself at school coteaching twice a week, having cogenerative dialogues and enacting these roles the rest of 


\section{Dossiê Especial: Experiências do PIBID na formação inicial e continuada de professores de línguas estrangeiras \\ HIBARINO \& NODARI (orgs) \\ Revista X, vol.1, 2015}

the week. In my view, supporting this definition of coteaching is also a way (a) to position cooperating teachers as accountable actors who are able to coteach with new teachers and guide them and therefore, actually enact the role of the teacher educator and (b) to implement coteaching in Brazilian context taking into consideration teacher educator's condition of work. This reconceptualization became an important key for my professional development and made me found my voice into the framework. Otherwise, the implementation of coteaching in Brazilian context will remain a matter of personal will instead of a useful and productive framework that suits our context.

Being on the same boat means either we swim together towards the continent or we sink together in the sea. The metaphor of "being in the same boat" suits this paper to exemplify our situation regarding teaching|learning in Brazil: either we work together (together meaning: having the same aim and not "doing everything together") and assume our own responsibility in the collectively responsibility to enhance learning during teaching practicum or we maintain the status quo looking for "scapegoats" I believe having new forms of participation at school might be a first step.

Another dimension of this study that implicated directly in my development was my approach to the "innovative" claim embedded in PIBID as a public policy. Although I do recognize that the "innovative claim" in public policies, in general, is based on the recognition of and an attempt to deal with what is perceived as a "crisis" in education and it functions as a way to support and incentivize new ways of participation, this claim might impact negatively during teaching education. I was, in the beginning, feeling the pressure to "innovate" and this would, many times, have an impact in new teachers. Talking to another teacher educator involved in PIBID program, we came to realize that if new teachers are expected to implement innovative teaching systems that they did not experience as learners and were not prepared for in their university course work by themselves might make new teachers feel discourage in not performing this role. I noticed our feeling concurred with the literature on the field: this also generates a great level of stress in new teachers as they are "teachingblind" having neither personal experience nor professional preparation for the role they are expected to undertake in this kind of endeavor. However, participating and writing about it showed me that as long as teachers decide by themselves they want to experience a new approach and have the opportunity to have it implemented in collaboration with more experienced teachers, having the support to deal with the tensions and contradictions that 


\section{Dossiê Especial: Experiências do PIBID na formação inicial e continuada de professores de línguas estrangeiras \\ HIBARINO \& NODARI (orgs) \\ Revista X, vol.1, 2015}

were part of the process, innovation comes as a result of the joint action rather than the primary aim.

The sense of belonging also came with the sense of proud and meaning in contributing to a context which was the context of my own development, first as an English teacher and later as a teacher educator. Being able (a) to continue the research and attempt to understand teachers' development in a well-known university alongside with colleagues that were my professors during the graduation, specialization, Master Degree and now in the Doctorate and (b) learning with them, everyday as part of my own job and development fells like belonging. In this sense, this paper is also about finding my own voice: about my own participation in a teacher education program as a way to shape my identity as a teacher educator enacting in teaching practicum.

Participating and writing this study also contributed to my 'becoming a teacher educator' in another dimension: as a researcher. I learned that at the same time I was teaching and therefore, participating at school in new ways, I was learning how to be a researcher and becoming a teacher educator by participating and writing this study. In this sense, I noticed how the research is an intrinsically and dialectical part of my work: it was by researching my participation and the participation of other teachers that I changed my way of participating. And by participating I researched even more.

\section{Final considerations}

In this paper, I addressed my experience of articulating Teaching practicum within PIBID and what have I learned - as a teacher educator in this context. What my personal experience and my previously studies tell me is that PIBID offers not only appropriate financial support, but also has the potential to subsidize different methodologies (e.g. \{coteaching|cogenerative dialogue $\}$ meetings) and new roles at schools (EL KADRI, 2014). PIBID, in this sense, appears to provide schoolteachers and novice teachers with solutions for dealing with such contradictions as it offers resources for the active participation of both. Thus, PIBID also offers a different perspective for understanding and conceptualizing teacher learning (including teacher educators' learning) in teacher education programs (sociohistorical-cultural approaches) (EL KADRI, 2014).

Thus, I argue that what PIBID represents in the field of Teacher Education is an initiative with the potential to reduce the asymmetries between members of the university 
Dossiê Especial: Experiências do PIBID na formação inicial e continuada de professores de

línguas estrangeiras

HIBARINO \& NODARI (orgs)

Revista X, vol.1, 2015

community (teacher educators and novice teachers) and members of the school community (teachers, novice teachers, teacher educators) by instituting spaces for collective action in the educative processes of teaching and learning. PIBID emerges as a potential social practice that helps overcome the technical-rationalist approach that persists in the majority of teacher education programs and therefore, provides support for socio-historical-cultural perspectives. That is why I prefer to adopt a positive perspective that affirms that these concepts may foster new and alternative methodologies for the teaching practicum.

I finish this article adding the research agenda for further investigations from EL KADRI (2014): the need to investigate how these contexts have altered or maintained the teacher educators' role. And all of these foci of research belong not only to PIBID and Teaching Practicum: our great challenge is to position PIBID in a way it re-organizes the structure of teacher education program curriculums in a whole. This article is only my representation of how I see PIBID embedded within the discipline I work with: Teaching practicum. Thus, I invite professors to adventure themselves to re-think their own area of expertise taking into account the experiences we are all having at our schools.

\section{Agradecimento}

Agradeço à CAPES pela concessão da bolsa de coordenadora de projeto PIBID que possibilitou a realização desta pesquisa.

\section{References}

ARRUDA, S. M.; BUENO, L. A. S. O PIBID /UEL e suas contribuições para a formação de professores de Londrina. IN: RIBEIRO, D. M.; CASTELA, G. S.; JUSTINA, L. D. (Org.). Formação de professores no Paraná: o PIBID em foco. Porto Alegre: Evangraf, 2013, Pp. 53-60.

AS NOVAS faces da reforma universitária do governo Lula e os impactos do PDE sobre a educação superior. Cadernos Andes, Brasília, n. 25, Pp. 1-41, ago. 2007.

BARCELOS, A. M. F.; BATISTA, F. S.; ANDRADE, J. C. Ser professor de Inglês: crenças, expectativas e dificuldades dos alunos de letras. IN: ABRAHÃO, M. H. V. (Org.). Prática de ensino de língua estrangeira: experiências e reflexões. Campinas: Pontes, 2004, Pp. 11-29.

BIAZI, T. M. D.; GIMENEZ, T.; STUTZ, L. O papel da observação de aulas durante o estágio supervisionado de Inglês. Signum: Estudos da Linguagem, Londrina, v. 14, n. 1, 2011, Pp. 57-78.

CASTELA, G. S. (Org.). Experiências bem sucedidas do PIBID na formação inicial de professores de língua espanhola. IN: CASTELA, G. S. (Org.). O PIBID como espaço de formação de professores em letras no Paraná. Porto Alegre: Evangraf, 2013a, Pp. 85-100. 
Dossiê Especial: Experiências do PIBID na formação inicial e continuada de professores de

línguas estrangeiras

HIBARINO \& NODARI (orgs)

Revista X, vol.1, 2015

CHIMENTÃO, L. K.; SOUZA-FIORI, A. Uma reflexão sobre os papeis exercidos por professores supervisores do PIBID . IN: MATEUS, E.; EL KADRI, M. S.; SILVA, K. A. (Org.). Experiências de formação de professores de línguas e o PIBID. Campinas: Pontes, 2013, Pp. 177-200.

CORREA, P. M.; PORTELA, V. C. M. As pesquisas sobre professores iniciantes no Brasil: uma revisão. Olhar de Professor, Ponta Grossa, v. 15, n. 2, 2012, Pp. 223-236.

CRISTOVÃO, V. L. C. et al. O estágio na formação de professores de inglês: um espaço de parceria? IN: CONGRESSO LATINO AMERICANO SOBRE FORMAÇÃO DE PROFESSORES, 2006, Florianópolis. Proceedings... Florianópolis: UFSC, 2006, Pp. 337347.

CRISTOVÃO, V. L. C. Por relações colaborativas entre universidades e escolas. IN: CRISTOVÃO, V. L. L.; GIMENEZ, T. ENFOPLI: construindo uma comunidade de formadores de professores de inglês. Londrina: Artgraf, 2005, Pp. 19-22.

DANIEL, F. G. Formação inicial do professor de língua inglesa: teoria e prática em questão. 2009. Tese (Doutorado em Estudos Linguísticos) - Universidade Estadual Paulista Júlio de Mesquita Filho, São José do Rio Preto, 2009.

EL KADRI, M. S. Concepções, pesquisas e desafios do PIBID letras inglês da UEL. IN: CASTELA, G. S. O PIBID como espaço de formação em letras no Paraná. Porto Alegre: Evangraf, 2013a, Pp. 75-84.

EL KADRI, M. S. Revisitando o estagio no curso de língua e literatura inglesa da UEL por meio da pesquisa: percursos, contribuições e desafios. IN: Os estágios nas licenciaturas da UEL. Londrina: UEL, 2013b, Pp. 61-86.

I am a PIBIDiana: societal relations as the locus of sustained development in a teacher education program in Brazil. IN: CONGRESSO BRASILEIRO DE LINGUÍSTICA APLICADA, 10., 2013, Rio de Janeiro. Proceedings... Rio de Janeiro: UFRJ, 2013c.

EL KADRI, M. S.; CHIMENTÃO, L. K. Ensino de língua inglesa e formação de professores de inglês: a proposta do "X-changing Ideas" no âmbito do PIBID. IN: JESUS, A. R. et al. Diálogos entre as licenciaturas e a educação básica: aproximações e desafios. Londrina: UEL, 2013, Pp. 137-144.

EL KADRI, M. S.; GIMENEZ, T. Mapeando práticas significativas no ensino língua inglesa: visões de professores participantes no PIBID - Uel. Revista Prodocencia, Londrina, v. 1, n. 3, 2013, Pp. 1-6.

EL KADRI, M. S.; PASSONI, T. Refletindo sobre avaliação em práticas de formação colaborativas: duas experiências no programa PIBID. IN: MATEUS, E.;EL KADRI, M. S; SILVA, K. A. (Org.). Experiências de formação de professores de línguas e o PIBID. Campinas: Pontes, 2013, Pp. 201-220.

EL KADRI, M. S.; PICONI, L.; MATEUS, E. Retratos do movimento universidade escola no interior do PIBID como pratica social. IN: MATEUS, E.; EL KADRI, M.S; SILVA, K. A. (Org.). Experiências de formação de professores de línguas e o PIBID. Campinas: Pontes, 2013, Pp. 105-130.

EL KADRI, M. S.; ROTH, W. M. "I am a PIBID iana": societal relations as the locus of sustained development in a teacher education program in Brazil. Australian Journal of Teacher Education, Perth, v. 38, 2013, Pp. 89-114. Available at: <http://ro.ecu.edu.au/ajte/vol38/iss5/7>. Accessed on: 5 Jan. 2014. 
Dossiê Especial: Experiências do PIBID na formação inicial e continuada de professores de línguas estrangeiras

HIBARINO \& NODARI (orgs)

Revista X, vol.1, 2015

EL KADRI, M. S.; ROTH, W. M. The teaching practicum as a locus of multileveled, schoolbased transformation. Teaching Education. 2015a.

EL KADRI, M. S. English language teachers' changing identities in a teaching practicum: PIBID and \{Coteaching|Cogenerative Dialogue $\}$ as opportunities for professional learning. 2014. 348 p. Doctoral dissertation (Doctorate in Language Studies) - State University of Londrina, Londrina, 2014.

FREIRE, P. Educação como prática da liberdade. Rio de Janeiro: Paz e Terra, 1967.

FURTOSO, V. B. et al. Parceria universidade; escolas: conquistas e desafios na formação de professores. IN: MATEUS, E. F.; QUEVEDO-CAMARGO, G.; GIMENEZ, T. (Org.). Ressignificações na formação de professores: rupturas e continuidades. Londrina: EDUEL, 2009, Pp. 45-60.

GAFFURI, P. As possibilidades mediadas pelo encontro com o outro. IN: MATEUS, E.; EL KADRI, M. S; SILVA, K. A. (Org.). Experiências de formação de professores de línguas e o PIBID. Campinas: Pontes, 2013, Pp. 155-165.

GAMERO, R.; CRISTOVÃO, V. L. L. A construção de identidade profissional no estágio de regência de inglês. Revista Prodocência, Londrina, v. 1, n. 3, p. 80-92, jan-jun. 2013. Avaiable at: 〈http://www.uel.br/revistas/prodocenciafope>. Accessed on: 5 Jan. 2014.

GIMENEZ, T. Crenças de licenciandos em Letras sobre o ensino de inglês. Signum, Londrina, v. 3, 2000, Pp. 125-139.

As práticas no curso de licenciatura em letras-inglês da Universidade Federal de Santa Catarina. IN: ABRAHÃO, M. H. V. (Org.). Prática de ensino de língua estrangeira: experiências e reflexões. Campinas: Pontes, 2004, Pp. 171-187.

Tecendo as manhãs: pesquisa participativa e formação de professores de inglês. Londrina: Fundação Araucária, 2007.

Práticas de Ensino em contexto tecnológico: primeiros apontamentos sobre a oferta de curso online. Revista Prodocencia, Londrina, n. 3, v. 1, p. 103-108, 2013 b.

. Formação de professores de línguas no Brasil: avanços e desafios. In: SANTOS, L. I. S.; SILVA, K. A. (Org.). Linguagem, ciência e ensino: desafios regionais e globais. Campinas: Pontes e ALAB, 2013a, Pp. 41-54.

Para além das questões linguísticas: ampliando a base de conhecimentos de professores de línguas estrangeiras. IN: MEDRADO, B. P.; REICHMANN, C. L. (Org.). Projetos e práticas na formação de professores de língua inglesa. João Pessoa: Ed. UFPB, 2012, Pp. 243-256.

GIMENEZ, T.; PEREIRA, F. M. Relação universidade/escola na formação de professores de inglês: primeiras aproximações. IN: GIMENEZ, T. (Org.). Tecendo as manhãs: pesquisa participativa e formação de professores de inglês. Londrina: Fundação Araucária, 2007.

JORDÃO, C. M. et al. O PIBID nas aulas de inglês: divisor de águas e formador de marés. Campinas: Pontes, 2013. v. 1.

JUSTINA, L. A. D.; RIBEIRO, D. M.; CASTELA, G. S. Introdução - O PIBID no estado do Paraná. IN: . Formação de professores no Paraná: o PIBID em foco. Porto Alegre:

Evangraf, 2013, Pp. 9-16. 
Dossiê Especial: Experiências do PIBID na formação inicial e continuada de professores de

línguas estrangeiras

HIBARINO \& NODARI (orgs)

Revista X, vol.1, 2015

MATEUS, E.; EL KADRI, M. S. Práticas significativas no ensino e na formação de professores/as de inglês: recriando realidades por meio do estágio no programa institucional de bolsa de iniciação à docência. IN: LIBERALI, F. C.; MATEUS, E.; DAMIANOVIC, M. C. A teoria da atividade sócio-histórico-cultural e a escola: recriando realidades sociais. Campinas: Pontes, 2012, Pp. 109-136.

MATEUS, E.; EL KADRI, M. S; SILVA, K. A. (Org.). Experiências de formação de professores de línguas e o PIBID. Campinas: Pontes, 2013.

ORTENZI, D. I. B. G. A construção de um artefato mediador da prática de ensino de inglês. 2007. Tese (Doutorado em Estudos da Linguagem) - Universidade Estadual de Londrina, Londrina, 2007a.

Avanços e lacunas nos estudos em formação de professores de língua inglesa no Brasil. ActaScientarium, Human and Social Science, Maringá, v. 29, 2007b, Pp. 121-127.

Em que consiste a força do NAP? IN: MATEUS, E.; QUEVEDO-CAMARGO, G.; GIMENEZ, T. (Org.). Ressignificações na formação de professores: rupturas e continuidades. Londrina: EDUEL, 2009, Pp. 195-200.

Mediações para a construção de parâmetros de avaliação do ensino numa perspectiva colaborativa. IN: MATEUS, E.; EL KADRI, M. S.; SILVA, K. A. (Org.). Experiências de formação de professores de línguas e o PIBID. Campinas: Pontes, 2013, Pp. 231-252.

ORTENZI, D. I. G. et al. (Org.). Com a palavra, os PIBID ianos: práticas de ensino e formação de professores de língua inglesa no contexto do PIBID . Londrina: Midiograf, 2014.

SOUZA-FIORI, A. G. Diários reflexivos na formação inicial de professoras de inglês: uma analise das marcas de modalidade e avaliação. Revista Prodocência, Londrina, v. 1, n. 3, p. 1-6, jan./jun. 2013.

RIBEIRO, D. M.; CASTELA, G. S.; JUSTINA, L. D. (Org.). Formação de professores no Paraná: o PIBID em foco. Porto Alegre: Evangraf, 2013.

RIBEIRO, D. M.; CASTELA, G. S.; LANGER, A. E. S. O PIBID - Unioeste: imersão reflexiva na prática docente. IN: RIBEIRO, D. M.; CASTELA, G. S.; JUSTINA, L. D. (Org.). Formação de professores no Paraná: o PIBID em foco. Porto Alegre: Evangraf, 2013, Pp 17-30.

ROTH, W. M.; TOBIN, K. At the elbow of another: learning to teach by co teaching. New York: Peter Lang, 2002a.

VYGOTSKIJ, L. Psyxhologijarazvitijačeloveka [Psychology of human development]. Moscow: Eksmo, 2005.

XAVIER, R. Universidade e escola: uma parceria para aprendizagem e ajuda mútua. IN: Convenção das Associações dos Professores de Inglês do Sul, 2006, Florianópolis. Proceedings... Florianópolis, 2006.

ZEULLI, E. et al. O PIBID e a formação inicial dos professores da UFTM: ações e experiências no cotidiano da escola pública. IN: Congresso Latino Americano de formação de professores de Línguas, 4., Brasília. Proceedings... Brasília: Universidade de Brasília, 2013. 